\title{
Electrochemical oxidation of textile azo dye reactive orange 16 on the Platinum electrode
}

\author{
Sanaa El Aggadi ${ }^{1,}$, Nidae Loudiyi ${ }^{1}$, Aicha Chadil ${ }^{1}$, Omar Cherkaoui ${ }^{2}$ and Abderrahim El Hourch ${ }^{1}$ \\ ${ }^{1}$ Materials, Nanotechnologies and Environment Laboratory, Chemistry Department, Faculty of Sciences, \\ Mohammed V University of Rabat, 4 Avenue Ibn Battouta, BP: 1014, Rabat, Morocco \\ ${ }^{2}$ School of Textile and Clothing Industries, Laboratory REMTEX, Km 8, Route d'El Jadida; BP 7731, Oulfa, \\ Casablanca, Morocco
}

\begin{abstract}
This study focused mainly on the color removal of textile azo dye Reactive Orange 16 (RO16) by electrochemical oxidation. The effect of supporting electrolyte $\left(\mathrm{H}_{2} \mathrm{SO}_{4}\right.$ and $\left.\mathrm{NaOH}\right), \mathrm{RO} 16$ concentration (from 0.5 to $10 \mathrm{mM}$ ) and potential scan rate (between 20 and $500 \mathrm{mV} / \mathrm{s}$ ) was performed with cyclic voltammetry using platinum $(\mathrm{Pt})$ wire as working electrode. The anodic peak current density was linear to RO16 concentrations. This allows the lowest concentrations to be determined voltammetrically in the two electrolytic media, acid $\left(\mathrm{H}_{2} \mathrm{SO}_{4} 1 \mathrm{M}\right)$ and alkaline $(\mathrm{NaOH} 0.1 \mathrm{M})$. Linearity between the current density and the square root of the potential scan rate was observed in both electrolytes. This means that the electrochemical reaction at the electrode-electrolyte interface is controlled by the diffusion process. The slope of the logarithm of peak current density versus the logarithm of potential scan rate was found to be 0.43 for $\mathrm{RO} 16$ in $\mathrm{H}_{2} \mathrm{SO}_{4}$ and 0.48 in $\mathrm{NaOH}$ these values of slop are close to the theoretical value of 0.5 which confirms the diffusion process. The removal efficiency of the dye in acid electrolyte reached $40 \%$, while it is $18 \%$ in the basic media after 4 hours of electrolysis by chronoamperometry.
\end{abstract}

Keywords: Reactive orange 16, Electrooxidation, Azo dyes, Cyclic voltammetry, Chronoamperometry.

\section{Introduction}

Dyes are colored substances, and resistant to fading on exposure to light, water and many chemicals due to their complex chemical structure and synthetic origin ${ }^{1,2}$, hence they persist in nature. More than 10,000 different commercially available dyes are used in textile industry for dyeing and printing purposes ${ }^{3,4}$. The estimated dyes concentration in the textile effluent has been reported to be in the range of $10-200 \mathrm{mg} \mathrm{L}^{-1} 3,5$. The discharge of dyecontaining effluents into receiving waters without appropriate treatment limits aquatic plant growth by creating anaerobic conditions ${ }^{6,7}$. Textile dyes are chemically diverse and are broadly divided into azo, reactive, triphenylmethane, heterocyclic, polymeric structures, etc ${ }^{8,9}$. The color of dyestuff in effluent interrupts the aquatic environment by reducing light penetration, gas solubility and interference of phytoplankton's photosynthesis ${ }^{10}$. In addition, the discharge of untreated effluent into usable water resources like rivers and lakes alters $\mathrm{pH}$ scale and will increase biological oxygen demand (BOD), chemical oxygen demand (COD) and total organic carbon (TOC) values ${ }^{11,12}$.
Azo dyes are the largest and most versatile dyes and are widely used in the textile processing, cosmetics, food, leather, and plastics industries ${ }^{13,14}$. More than $60 \%$ of dyestuffs manufactured around the world are azo dyes ${ }^{15}$, During the dyeing process, a large quantity of these dyes is released into wastewater streams 16,17, which are recalcitrant, no biodegradable, carcinogenic, mutagenic, and toxic ${ }^{18}$.

Azo dyes represent about $70 \%$ of the world dye production and are extensively used in textile industries. They contain one or more azo bonds $(-\mathrm{N}=\mathrm{N}-)$ as chromophore group in association with aromatic structures containing functional groups such as $-\mathrm{OH}$ and $-\mathrm{SO}_{3} \mathrm{H}{ }^{19,20}$. Azo dyes are now classified as an environmentally hazardous material ${ }^{21}$, so their release into wastewater streams without proper treatment could have serious environmental implications ${ }^{22-24}$. The environmental legislation about the appearance of color in discharged effluent has forced the industries to treat dyestuff containing effluent themselves ${ }^{25}$. 
Additionally, limited supply and increasing cost of water for the industrial sector have made the treatment and reuse of dyeing effluent mandatory to avoid environmental pollution and reduce production cost. A variety of typical Physico-chemical strategies such as coagulation, flocculation, activated carbon adsorption and reverse osmosis technique are used for the removal of color from textile effluent ${ }^{26-29}$.

However, excessive use of chemicals in such conventional treatments produces a large amount of sludge and does not remove all dyes ${ }^{30}$, thus preventing recycling of treated effluent.

In addition, excess use of chemicals requires high cost and results in secondary pollution ${ }^{31,32}$. Besides its environmental compatibility, the electrochemical process presents important advantages related to its versatility, high energy efficiency, amenability of automation and safety because it operates at mild conditions ${ }^{33-45}$. The objective of this study was to investigate the efficiency of decolorization of the widely used textile azo dye with the electrochemical oxidation. In this context, RO16 an anionic sulphonated reactive azo dye was selected as a model pollutant because it is difficult to biodegrade ${ }^{46}$. It has molecular formula $\mathrm{C}_{20} \mathrm{H}_{17} \mathrm{~N}_{3} \mathrm{Na}_{2} \mathrm{O}_{11} \mathrm{~S}_{3}$ (Molecular weight: $617.5 \mathrm{~g} / \mathrm{mol}$ ) with Color Index Number (C.I. 17757). The structural formula of RO16 is shown in Fig. ${ }^{47-49}$.<smiles>CC(=O)Nc1ccc2cc(S(=O)(=O)O[Na])c(N=Nc3cccc(S(=O)(=O)CCOS(=O)(=O)O[Na])c3)c(O)c2c1</smiles>

Figure 1. Structural formula of the Reactive Orange 16 (RO16) azo dye

\section{Results and Discussion}

\subsection{Effect of electrolyte in RO16 electrooxidation} Fig. 2 shows the voltammograms of $1 \mathrm{M} \mathrm{H}_{2} \mathrm{SO}_{4}$ $(\mathrm{pH}=0)$ and $0.1 \mathrm{M} \mathrm{NaOH}(\mathrm{pH}=13)$ with and without $10 \mathrm{mM}$ RO16 dye at a potential scan rate of $100 \mathrm{mV} / \mathrm{s}$ on Pt electrode.

For the voltammogram of $\mathrm{H}_{2} \mathrm{SO}_{4}$ without $\mathrm{RO} 16$ dye a wide anodic peak-like is observed from $0.8 \mathrm{~V} / \mathrm{SCE}$, due to the $\mathrm{Pt}$ oxidation, whereas one peak is observed at $0.5 \mathrm{~V} / \mathrm{SCE}$ in the cathodic region, due to the $\mathrm{Pt}$ oxides reduction ${ }^{50}$. For the voltammogram of $\mathrm{H}_{2} \mathrm{SO}_{4}$ containing $\mathrm{RO} 16$ dye, two anodic peaks can be observed at $0.4 \mathrm{~V} / \mathrm{SCE}$ and $1.35 \mathrm{~V} / \mathrm{SCE}$, which is attributed to the oxidation reaction of RO16 dye. In addition, a broad cathodic peak-like is observed over the potential range $0.7-0.9 \mathrm{~V} / \mathrm{SCE}$ and a cathodic peak at $-0.1 \mathrm{~V} / \mathrm{SCE}$ (Fig.2a).

For the black voltammogram of $\mathrm{NaOH}$, a wide anodic peak-like is observed from $-0.1 \mathrm{~V} / \mathrm{SCE}$, due to the Pt oxidation, whereas one peak is observed at
$-0.45 \mathrm{~V} / \mathrm{SCE}$ in the cathodic region, due to the $\mathrm{Pt}$ oxides reduction ${ }^{51}$.

For the blue voltammogram, two anodic peaks are observed, the first at $-0.2 \mathrm{~V} / \mathrm{SCE}$ and the second at $0.5 \mathrm{~V} / \mathrm{SCE}$, and in the cathodic region there is a large peak in the potential range $0-0.2 \mathrm{~V} / \mathrm{SCE}$ and a peak at -0.9 V/SCE (Fig.2b).

In both electrolytes, the first anodic peak only appeared during the next scan after the reduction step, so this peak was obviously due to the corresponding oxidation of the reduction products.

As reported in previous studies ${ }^{52,53}$, azo dyes with a hydroxyl group adjacent to an azo bridge were reduced, producing a corresponding amine, which was more susceptible to reoxidation in the return analysis.

The presence of peaks in both electrolytes means that RO16 oxidizes easily on the Pt electrode surface. 

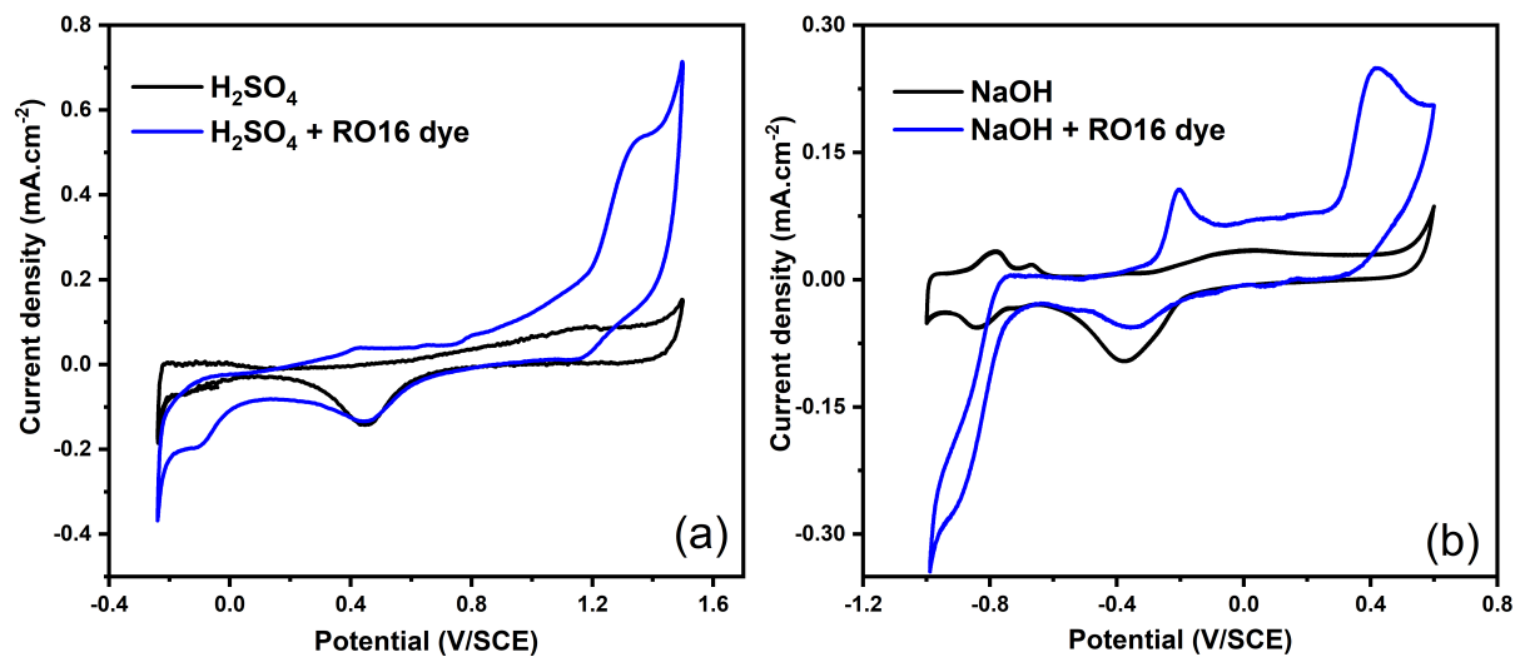

Figure 2. Cyclic voltammograms plotted on Pt electrode at $100 \mathrm{mV} / \mathrm{s}$ of $10 \mathrm{mM}$ RO16 dye in: (a) $\mathrm{H}_{2} \mathrm{SO}_{4}(1 \mathrm{M})$ and (b) $\mathrm{NaOH}(0.1 \mathrm{M})$

\subsection{Effect of RO16 concentration}

Fig.3 shows cyclic voltammograms recorded for different concentrations $(0.5,1,2,5,10 \mathrm{mM})$ of RO16 dye in $\mathrm{H}_{2} \mathrm{SO}_{4}(1 \mathrm{M})$ and $\mathrm{NaOH}(0.1 \mathrm{M})$ at a potential scan rate of $50 \mathrm{mV} / \mathrm{s}$.

In the potential range of -0.24 and $1.5 \mathrm{~V} / \mathrm{SCE}$, it is observed that as the RO16 dye concentration increases the anodic peaks current density increases and their position shifts to higher potential values (Fig.3a). The inset plot shows the linear relation between the peak current (Ip) and RO16 dye concentration in the range $0.5-10 \mathrm{mM}$. Hence, the corresponding linear regression equation is Ip $=0.02 \mathrm{C}+0.13$ with the correlation coefficient of $\mathrm{R}^{2}=0.99$.

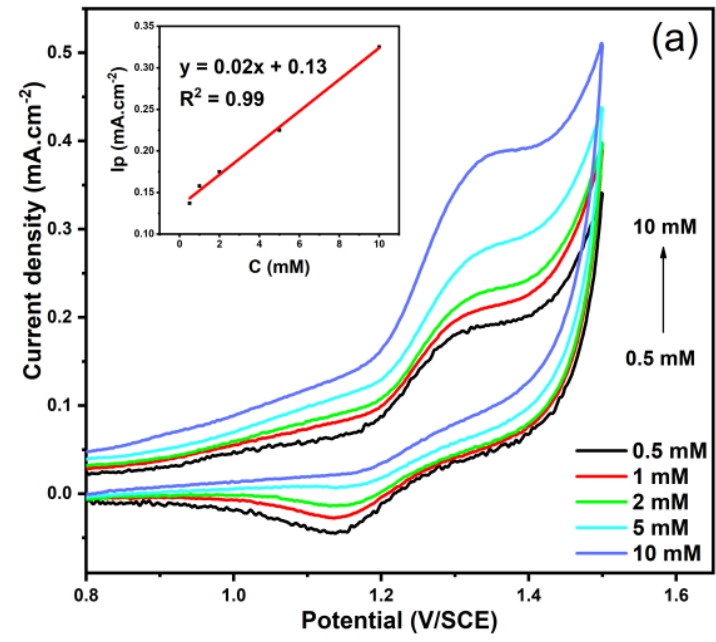

From Fig.3b, we can be seen that the anodic peak currents are increased and their position shifts to higher potential values with increasing the RO16 concentration. The inset in panel shows that the oxidation peak current density varies linearly with the dye concentration:

$\left(\left(\mathrm{Ip}=0.02 \mathrm{C}+0.01, \mathrm{R}^{2}=0.99\right)\right.$.

These results indicate that even RO16 dye concentrations lower than the millimolar can be detected by $\mathrm{Pt}$ electrode as well as used for the determination and analysis of the dye during its degradation.

Figure 3. Cyclic voltammograms recorded at Pt electrode with scan rate of $50 \mathrm{mV} / \mathrm{s}$ for different concentrations of RO16 dry in: (a) $\mathrm{H}_{2} \mathrm{SO}_{4}$ and (b) $\mathrm{NaOH}$. Insert current density versus $\mathrm{RO} 16$ dye concentration

\subsection{Effect of potential scan rate}

The relationship between peak current and potential scan rate provides useful information on the electrochemical mechanism. At different potential scan rates, the electrochemical behavior of RO16 was studied by applying a cyclic voltammetric

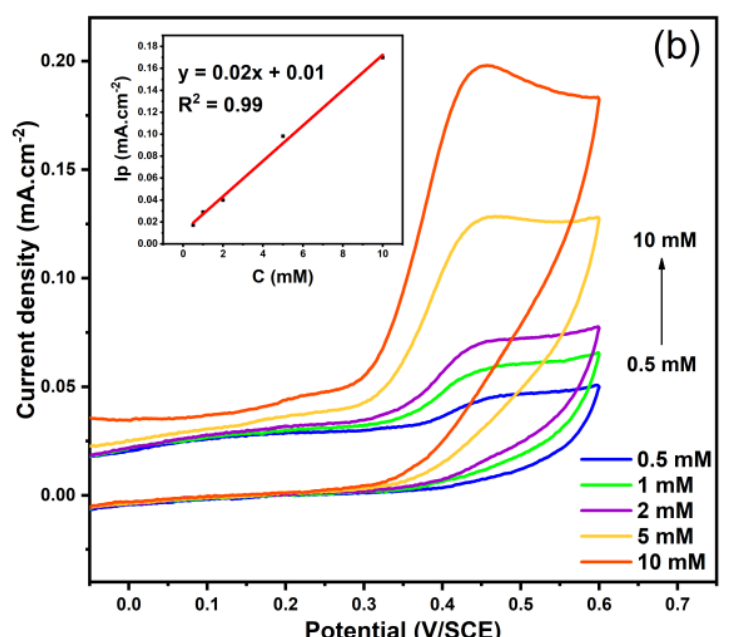

technique. Fig.4 and Fig.5 show the voltammograms recorded on a Pt electrode by varying the potential scan rate from 20 to $500 \mathrm{mV} / \mathrm{s}$ of $10 \mathrm{mM}$ RO16 dye in $\mathrm{H}_{2} \mathrm{SO}_{4}(1 \mathrm{M})$ and $\mathrm{NaOH}(0.1 \mathrm{M})$, respectively.

From Fig.4a, as the potential scan rate increased, the oxidation peaks current (Ip) also increased, and the 
peak potential (Ep) shifts to higher potential values, typical of irreversible systems (Fig.4a). The graph of peak current versus square root of scan rate is linear over the range of potential scan rate studied (Fig.4b), which indicates that it is a typical diffusioncontrolled current system, and the equation can be expressed as $I p=1.12 \mathrm{v}^{1 / 2}+0.06, \mathrm{R}^{2}=0.99$.

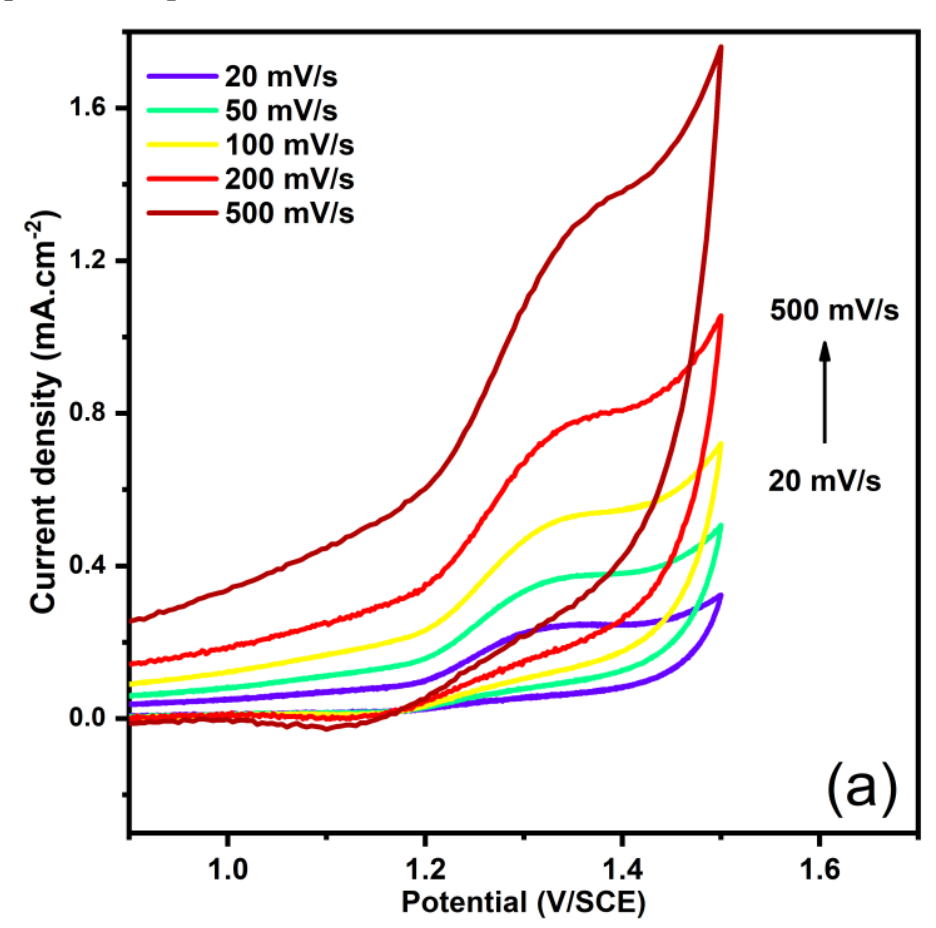

A logarithm of peak current, log (Ip), versus the logarithm of potential scan rate, $\log \mathrm{v}$, was also studied (Fig.4c). This relationship was found to be linear, $\left(\log \mathrm{Ip}=0.43 \log \mathrm{v}+0.06, \mathrm{R}^{2}=0.99\right)$ with a slope, 0.43 , which is near to the theoretical value of 0.5 for a diffusion controlled process ${ }^{54}$.
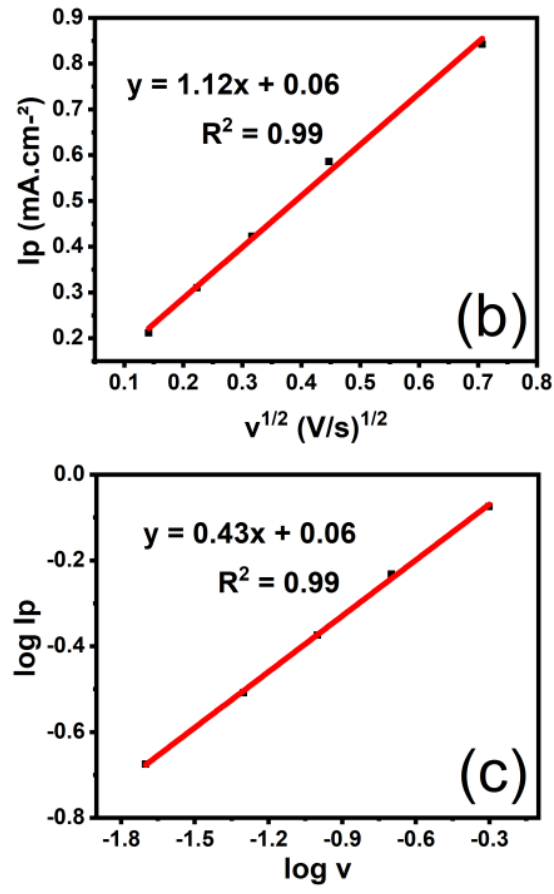

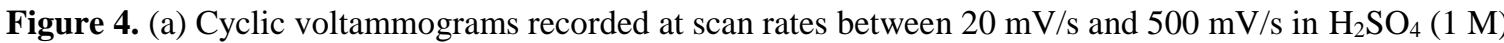
containing $10 \mathrm{mM}$ RO16 dye. (b) Graph of peak current versus square root of scan rate. (c) Graph of the logarithm of peak current versus the logarithm of scan rate
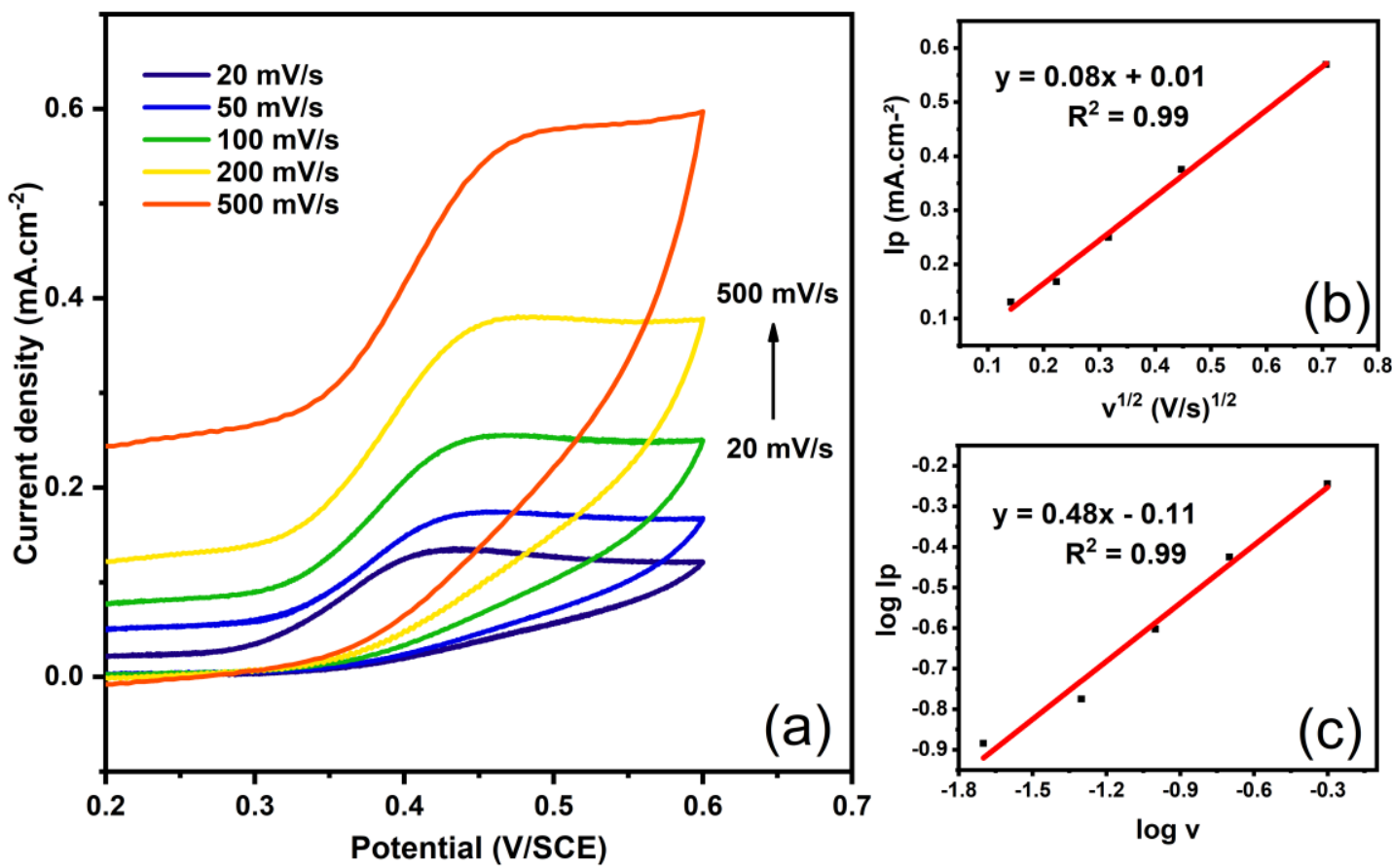

Figure 5. (a) Cyclic voltammograms recorded at potential scan rates between $20 \mathrm{mV} / \mathrm{s}$ and $500 \mathrm{mV} / \mathrm{s}$ in NaOH $(0.1 \mathrm{M})$ containing $10 \mathrm{mM}$ RO16 dye. (b) Graph of peak current versus square root of scan rate. (c) Graph of the logarithm of peak current versus the logarithm of scan rate 
According to Fig.5a, as the potential scan rate increased, the oxidation peaks current (Ip) also increased, and the peak potential (Ep) moves towards higher potential values, typical of irreversible systems. The graph of peak current versus square root of scan rate is linear over the range of scan rate studied (Fig.5b), which indicates that it is a typical diffusion-controlled current system, and the equation can be expressed as $\mathrm{I} p=0.08 \mathrm{v}^{1 / 2}+0.01, \mathrm{R}^{2}=0.99$.

\subsection{Electrolysis of RO16 dye by chrono-} amperometry

The RO16 dye electrolysis experiment was performed using chronoamperometry at a fixed potential (1.4 V/SCE for $\mathrm{H}_{2} \mathrm{SO}_{4}$ and $0.6 \mathrm{~V} / \mathrm{SCE}$ for $\mathrm{NaOH}$ ) for 4 hours (Fig.6). The curves exhibit the typical current drop in the very first seconds

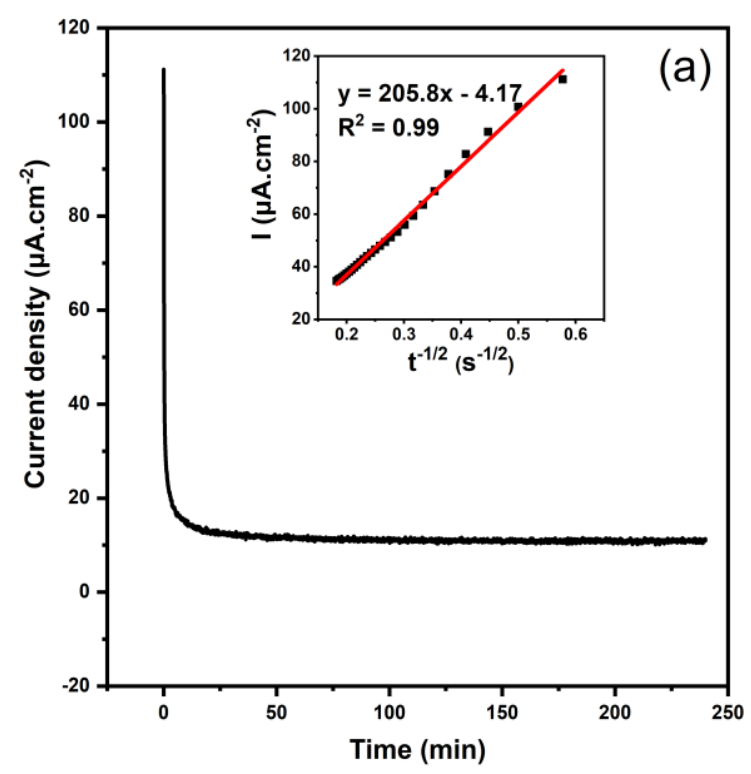

A logarithm of peak current, log (Ip), versus the logarithm of potential scan rate, $\log \mathrm{v}$, was also studied (Fig.5c). This relationship was found to be linear, $\left(\log \mathrm{Ip}=0.48 \log \mathrm{v}-0.11, \mathrm{R}^{2}=0.99\right)$. The value of the slope is close to the theoretical value of 0.5 for a diffusion-controlled mechanism ${ }^{54}$. The results of these experimental studies suggest that the electrooxidation of RO16 dye on the Pt electrode is mainly controlled by diffusion. associated to the oxidation of RO16 adsorbed on the catalyst thin layer, followed by a slower variation with time, ascribed to the oxidation of RO16 under steady-state conditions. The linear relationship between current density and the reciprocal of the square root of time for both electrolytes was shown in Fig.6 (Insert). This indicates that the transient current must be controlled by a diffusion process.

Figure 6. Chronoamperometry curve of $10 \mathrm{mM}$ RO16 dye dissolved in: (a) $\mathrm{H}_{2} \mathrm{SO}_{4}(1 \mathrm{M})$ for $4 \mathrm{~h}$ at $1.4 \mathrm{~V} / \mathrm{SCE}$ and (b) $\mathrm{NaOH}(0.1 \mathrm{M})$ for $4 \mathrm{~h}$ at $0.6 \mathrm{~V} / \mathrm{SCE}$. Insert plot of I versus $\mathrm{t}^{-1 / 2}$ obtained from chronoamprogram
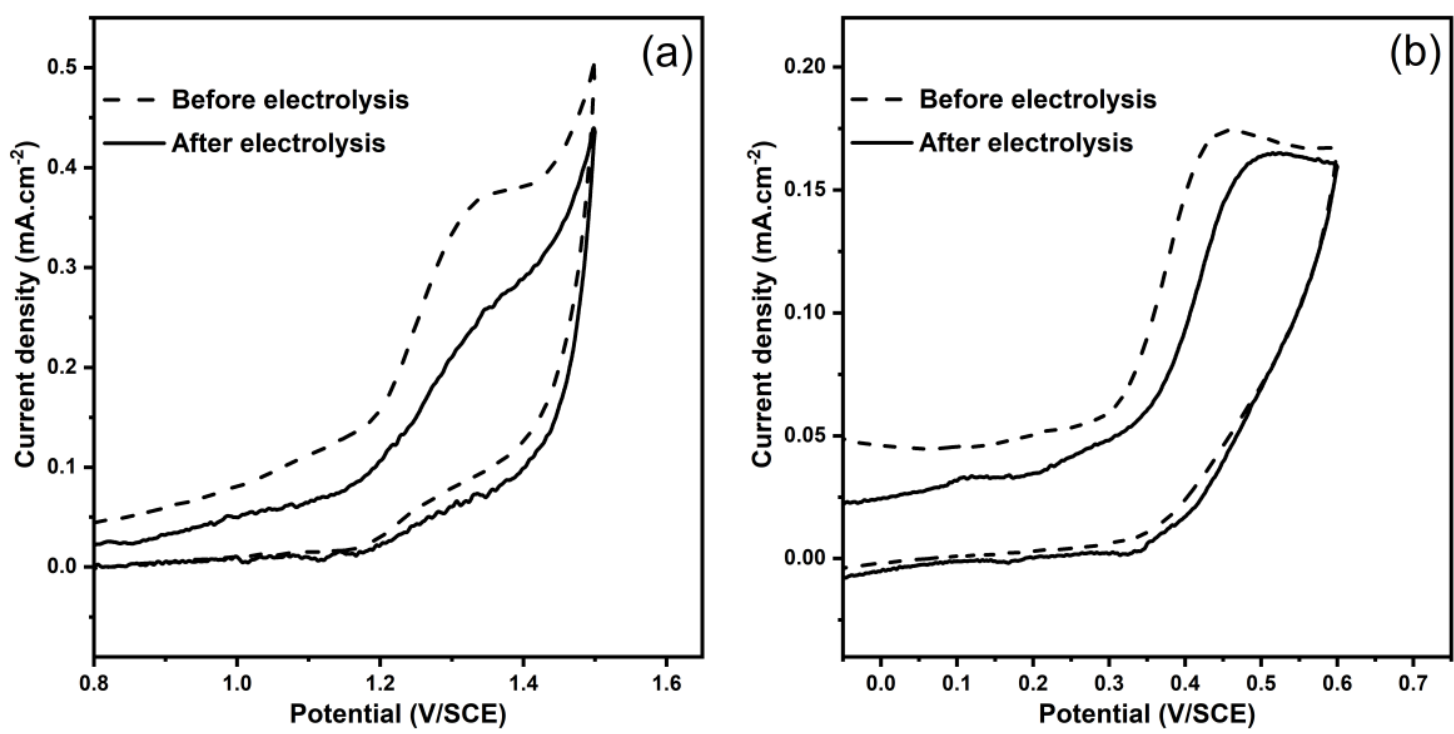

Figure 7. Cyclic voltammograms recorded before (solid line) and after (dashed line) the chronoamperometry at potential scan rate of $50 \mathrm{mV} / \mathrm{s}$ of $10 \mathrm{mM}$ RO16 dye dissolved in: (a) $\mathrm{H}_{2} \mathrm{SO}_{4}(1 \mathrm{M})$ and (b) $\mathrm{NaOH}(0.1 \mathrm{M})$ 
The evaluation of RO16 dye concentration after chronoamperometric treatment using a Pt electrode after 4 hours of electrolysis was performed using cyclic voltammetric detection with the same electrode. Fig.7 shows cyclic voltammograms recorded for initial RO16 dye concentration and after chronoamperometry applying. The percentage of dye removal was calculated according to the following equation ${ }^{55}$ :

$$
\mathrm{R} \%=\frac{\mathrm{C}_{0}-\mathrm{C}}{\mathrm{C}_{\mathrm{o}}} \times 100
$$

Where $\mathrm{C}_{\mathrm{o}}$ and $\mathrm{C}$ are the initial and after electrolysis concentrations of the dye $(\mathrm{mol} / \mathrm{L})$, respectively.

After electrolysis, a sharp decrease in the RO16 peak was observed for both medium; it means that the concentration is reduced after the treatment. In acidic medium, the dye removal efficiency is $40 \%$, however, $18 \%$ in alkaline medium. We can affirm that the $\mathrm{H}_{2} \mathrm{SO}_{4}(1 \mathrm{M})$ solution showed an excellent electrolytic performance towards the electrooxidation of RO16 compared to $\mathrm{NaOH}(0.1$ M) solution.

\section{Conclusion}

The present work is devoted to the electrochemical oxidation of textile azo dye RO16 in both acid and basic mediums at Pt electrode. Cyclic voltammetry technique was used to perform the effect of supporting electrolyte, RO16 concentration and potential scan rate. The electrochemical process is diffusion-controlled and the oxidation peak current density of RO16 was linearly proportional to its concentration in a range from $0.5 \mathrm{mM}$ to $10 \mathrm{mM}$. For the same operating variables, the acid medium proved to be the most favorable medium for active degradation of RO16 dye. The percentage of dye removal was found to be $40 \%$ in acidic medium and about $18 \%$ in the alkaline medium after $4 \mathrm{~h}$ of electrolysis. Thus, electrochemical technology is an effective method for the removal of RO16 dye from the effluents of the textile industry.

\section{Experimental}

The electrochemical oxidation was carried out in a three-electrode cell $(50 \mathrm{ml})$ with the Platinum $(\mathrm{Pt})$ wire $\left(0.2 \mathrm{~cm}^{2}\right)$ as a working electrode (WE), a saturated calomel electrode (SCE) as a reference electrode (RE) and glassy carbon as a counter electrode (CE). The cyclic voltammetry measurements and chronoamperometry were performed using a PGZ 301 Potentiostat/ Galvanostat monitored by VoltaMastrer 4 software.

Sulphuric acid (96\%, Sigma-Aldrich) and sodium hydroxide (99.99\%, Sigma-Aldrich) were used for the preparation of the base electrolytes: $1 \mathrm{M} \mathrm{H}_{2} \mathrm{SO}_{4}$ and $0.1 \mathrm{M} \mathrm{NaOH}$, respectively. All solutions were prepared with ultrapure water (18 M $2 . \mathrm{cm}-1)$. Before each scan the electrode was prepared to ensure a reproducible surface by polishing, rinsing with distilled water and then electrochemically cleaned by cyclic voltammetry in $1 \mathrm{M}$ of the sulfuric acid solution until a reproducible voltammogram was obtained. All the electrochemical experiments were carried out at $25^{\circ} \mathrm{C}$.

\section{References}

1- A. Gürses, M. Açıkyıldız, K. Güneş, M. S. Gürses, Dyes and Pigments: Their Structure and Properties, 2016, pp. 13-29.

2- V. J. P. Poots, G. McKay, J. J. Healy, The removal of acid dye from effluent using natural adsorbents-I peat, Water Res., 1976, 10, 1061-1066.

3- A. A. Kadam, A. A. Telke, S. S. Jagtap, S. P. Govindwar, Decolorization of adsorbed textile dyes by a developed consortium of Pseudomonas sp. SUK1 and Aspergillus ochraceus NCIM-1146 under solid-state fermentation, J. Hazard. Mater., 2011, 189, 486-494.

4- A. Hasanbeigi, L. Price, A technical review of emerging technologies for energy and water efficiency and pollution reduction in the textile industry, J. Clean. Prod., 2015, 95, 30-44.

5- H. Y. El-Kassas, L. A. Mohamed, Bioremediation of the textile waste effluent by Chlorella vulgaris, Egypt. J. Aquat. Res., 2014, 40, 301-308.

6- O. Yesilada, D. Asma, S. Cing, Decolorization of textile dyes by fungal pellets, Process Biochem., 2003, 38, 933-938.

7- I. M. Banat, P. Nigam, D. Singh, R. Marchant, Microbial decolorization of textiledyecontaining effluents: A review, Bioresour. Technol., 1996, 58, 217-227.

8- T. Cheunbarn, S. Cheunbarn, T. Khumjai, Prospects of bacterial granule for treatment of real textile industrial wastewater, Int J Agric Biol., 2008, 10, 689-92.

9- N. Muhd Julkapli, S. Bagheri, S. Bee Abd Hamid, Recent advances in heterogeneous photocatalytic decolorization of synthetic dyes, Sci. World J., 2014, 2014, 25.

10- V. K. Sharma, Aggregation and toxicity of titanium dioxide nanoparticles in aquatic environment-A Review, J. Environ. Sci. Heal. Part A., 2009, 44, 1485-1495.

11-H. S. Lade, T. R. Waghmode, A. A. Kadam, S. P. Govindwar, Enhanced biodegradation and detoxification of disperse azo dye Rubine GFL and textile industry effluent by the defined fungal-bacterial consortium, Int. Biodeterior. Biodegradation., 2012, 72, 94-107.

12-S. Dixit, A. Yadav, P. D. Dwivedi, M. Das, Toxic hazards of leather industry and technologies to combat threat: A review, J. Clean. Prod., 2015, 87, 39-49.

13-M. -M. Zhang, W. -M. Chen, B. -Y. Chen, C. T. 
Chang, C. -C. Hsueh, Y. Ding, K. -L. Lin, H. $\mathrm{Xu}$, Comparative study on characteristics of azo dye decolorization by indigenous decolorizers, Bioresour. Technol., 2010, 101, 2651-2656.

14-F. P. Van der Zee, F. J. Cervantes, Impact and application of electron shuttles on the redox (bio)transformation of contaminants: A review, Biotechnol. Adv., 2009, 27, 256-277.

15-R. G. Saratale, G. D. Saratale, J. S. Chang, S. P. Govindwar, Ecofriendly degradation of sulfonated diazo dye C.I. Reactive Green 19A using Micrococcus glutamicus NCIM-2168, Bioresour. Technol., 2009, 100, 3897-3905.

16-H. Ben Mansour, D. Barillier, D. Corroler, K. Ghedira, L. Chekir-Ghedira, R. Mosrati, In Vitro Study Of DNA Damage Induced By Acid Orange 52 and its Biodegradation Derivatives, Environ. Toxicol. Chem., 2009, 28, 489.

17-C. G. Boer, L. Obici, C. G. M. de Souza, R. M. Peralta, Decolorization of synthetic dyes by solid-state cultures of Lentinula (Lentinus) edodes producing manganese peroxidase as the main ligninolytic enzyme, Bioresour. Technol., 2004, 94, 107-112.

18-C. Özdemir, M. K. Öden, S. Şahinkaya, E. Kalipçi, Color Removal from Synthetic Textile Wastewater by Sono-Fenton Process, CLEAN- Soil, Air, Water., 2011, 39, 60-67.

19-C. A. Martínez-Huitle, E. Brillas, Decontamination of wastewaters containing synthetic organic dyes by electrochemical methods: A general review, Appl. Catal. B Environ., 2009, 87, 105-145.

20-J. M. Peralta-Hernández, M. Méndez-Tovar, R. Guerra-Sánchez, C. A. Martínez-Huitle, J. L. Nava, A Brief Review on Environmental Application of Boron Doped Diamond Electrodes as a New Way for Electrochemical Incineration of Synthetic Dyes, Int. J. Electrochem., 2012, 2012, 1-18.

21-S. M. de A. G. U. de Souza, K. A. S. Bonilla, A. A. U. de Souza, Removal of COD and color from hydrolyzed textile azo dye by combined ozonation and biological treatment, J. Hazard. Mater., 2010, 179, 35-42.

22-E. R. Bandala, M. A. Peláez, A. J. GarcíaLópez, M. de J. Salgado, G. Moeller, Photocatalytic decolourisation of synthetic and real textile wastewater containing benzidinebased azo dyes, Chem. Eng. Process. Process Intensif., 2008, 47, 169-176.

23-A. A. Pourbabaee, F. Malekzadeh, M. N. Sarbolouki, F. Najafi, Aerobic Decolorization and Detoxification of a Disperse Dye in Textile Effluent by a New Isolate of Bacillus sp., Biotechnol. Bioeng., 2006, 93, 631-635.

24-E. Forgacs, T. Cserháti, G. Oros, Removal of synthetic dyes from wastewaters: a review, Environ. Int., 2004, 30, 953-971.

25-T. Robinson, G. McMullan, R. Marchant, P. Nigam, Remediation of dyes in textile effluent: a critical review on current treatment technologies with a proposed alternative, Bioresour. Technol., 2001, 77, 247-255.

26-F. Moughaoui, A. Ouaket, A. Laaraibi, S. Hamdouch, Z. Anbaoui, A. Abourriche, M. Berrada, A novel approach for producing low cost and highly efficient activated carbon for removing cationic dyes, Mediterr. J. Chem., 2019, 8, 74-83.

27-Z. Zakaria, M. R. Othman, S. Z. Hasan, W. Y. Wan Ahmad, Electrochemical Degradation of Reactive Orange 16 by using Charcoal-Based Metallic Composite Electrodes, Sains Malaysiana., 2019, 48, 791-801.

28-A. AM, F. Ouzidan, T. Ainane, M. Talbi, M. El Kouali, Adsorption of cationic dye onto Moroccan natural rock, Mediterr. J. Chem., 2019, 9, 37.

29-B. Mella, B. S. de C. Barcellos, D. E. da Silva Costa, M. Gutterres, Treatment of Leather Dyeing Wastewater with Associated Process of Coagulation-

Flocculation/Adsorption/Ozonation, Ozone Sci. Eng., 2018, 40, 133-140.

30-K. Paździor, A. Klepacz-Smółka, S. Ledakowicz, J. Sójka-Ledakowicz, Z. Mrozińska, R. Żyłła, Integration of nanofiltration and biological degradation of textile wastewater containing azo dye, Chemosphere., 2009, 75, 250-255.

31-J. P. Jadhav, G. K. Parshetti, S. D. Kalme, S. P. Govindwar, Decolourization of azo dye methyl red by Saccharomyces cerevisiae MTCC 463, Chemosphere., 2007, 68, 394-400.

32-M. Behnajady, N. Modirshahla, H. Fathi, Kinetics of decolorization of an azo dye in UV alone and $\mathrm{UV} / \mathrm{H}_{2} \mathrm{O}_{2}$ processes, J. Hazard. Mater., 2006, 136, 816-821.

33-V. Erady, R. J. Mascarenhas, A. K. Satpati, A. K. Bhakta, Z. Mekhalif, J. Delhalle, A. Dhason, Carbon paste modified with Bi decorated multiwalled carbon nanotubes and CTAB as a sensitive voltammetric sensor for the detection of Caffeic acid, Microchem. J., 2019, 146, 73-82.

34-N. P. Shetti, D. S. Nayak, S. J. Malode, R. M. Kulkarni, D. B. Kulkarni, R. A. Teggi, V. V. Joshi, Electrooxidation and determination of flufenamic acid at graphene oxide modified carbon electrode, Surfaces and Interfaces., 2017, 9, 107-113.

35-S. D. Bukkitgar, N. P. Shetti, Electrochemical behavior of an anticancer drug 5-fluorouracil at methylene blue modified carbon paste electrode, Mater. Sci. Eng. C., 2016, 65, 262-268.

36-N. P. Shetti, D. S. Nayak, G. T. Kuchinad, R. R. Naik, Electrochemical behavior of thiosalicylic acid at $\gamma-\mathrm{Fe}_{2} \mathrm{O}_{3}$ nanoparticles and clay composite carbon electrode, Electrochim. Acta., 2018, 269, 204-211.

37-U. Ghimire, M. Jang, S. Jung, D. Park, S. Park, H. Yu, S. -E. Oh, Electrochemical Removal of Ammonium Nitrogen and COD of Domestic 
Wastewater using Platinum Coated Titanium as an Anode Electrode, Energies, 2019, 12, 883.

38-M. Jović, D. Stanković, D. Manojlović, I. Anđelković, A. Milić, B. Dojčinović, G. Roglić, Study of the Electrochemical Oxidation of Reactive Textile Dyes Using Platinum Electrode, Int. J. Electrochem. Sci., 2013, 8, 168-183.

39-O. J. D’Souza, R. J. Mascarenhas, A. K. Satpati, B. M. Basavaraja, A novel $\mathrm{ZnO} /$ reduced graphene oxide and Prussian blue modified carbon paste electrode for the sensitive determination of Rutin, Sci. China Chem., 2019, 62, 262-270.

40-D. B. Shikandar, N. P. Shetti, R. M. Kulkarni, S. D. Kulkarni, Silver-doped titania modified carbon electrode for electrochemical studies of furantril, ECS J. Solid State Sci. Technol., 2018, 7, Q3215-Q3220.

41-S. Kumar, S. D. Bukkitgar, S. Singh, Pratibha, V. Singh, K. R. Reddy, N. P. Shetti, C. Venkata Reddy, V. Sadhu, S. Naveen, Electrochemical Sensors and Biosensors Based on Graphene Functionalized with Metal Oxide Nanostructures for Healthcare Applications, ChemistrySelect., 2019, 4, 5322-5337.

42-A. K. Bhakta, S. Kumari, S. Hussain, P. Martis, R. J. Mascarenhas, J. Delhalle, Z. Mekhalif, Synthesis and characterization of maghemite nanocrystals decorated multi-wall carbon nanotubes for methylene blue dye removal, J. Mater. Sci., 2019, 54, 200-216.

43-N. Shetti, D. Nayak, Electrochemical detection of chlorpheniramine maleate in the presence of an anionic surfactant and its analytical applications, Can. J. Chem., 2017, 95, 553-559.

44-S. D. Bukkitgar, N. P. Shetti, R. M. Kulkarni, K. R. Reddy, S. S. Shukla, V. S. Saji, T. M. Aminabhavi, Electro-catalytic behavior of $\mathrm{Mg}$ doped $\mathrm{ZnO}$ nano-flakes for oxidation of antiinflammatory drug, J. Electrochem. Soc., 2019, 166, B3072-B3078.

45-N. P. Shetti, S. J. Malode, R. S. Malladi, S. L. Nargund, S. S. Shukla, T. M. Aminabhavi, Electrochemical detection and degradation of textile dye Congo red at graphene oxide modified electrode, Microchem. J., 2019, 146, 387-392.
46-C. -Y. Chen, Photocatalytic Degradation of Azo Dye Reactive Orange 16 by $\mathrm{TiO}_{2}$, Water. Air. Soil Pollut., 2009, 202, 335-342.

47-L. S. Andrade, T. T. Tasso, D. L. da Silva, R. C. Rocha-Filho, N. Bocchi, S. R. Biaggio, On the performances of lead dioxide and boron-doped diamond electrodes in the anodic oxidation of simulated wastewater containing the Reactive Orange 16 dye, Electrochim. Acta., 2009, 54, 2024-2030.

48-S. W. Won, S. B. Choi, Y. S. Yun, Performance and mechanism in binding of Reactive Orange 16 to various types of sludge, Biochem. Eng. J., 2006, 28, 208-214.

49-Z. Zakaria, N. Nordin, S. Zubaidah Hasan, N. Afzalina Baharuddin, M. Ahmed Jumaah, M. Rozali Othman, Decolorization of reactive orange 16 dye using a fabricated charcoal base metallic composite electrode, Malaysian J. Anal. Sci., 2015, 19, 493-502.

50-N. Farfour, M. El Mahi Chbihi, D. Takky, K. Eddahaoui, S. Benmokhtar, Catalytic oxidation of methanol on $\mathrm{Pt} / \mathrm{X}(\mathrm{X}=\mathrm{CaTP}$, NaTP) electrodes in sulfuric acid solution, Mediterr. J. Chem., 2013, 2, 595-606.

51-K. M. Hassan, A. A. Hathoot, R. Maher, M. Abdel Azzem, Electrocatalytic oxidation of ethanol at $\mathrm{Pd}, \mathrm{Pt}, \mathrm{Pd} / \mathrm{Pt}$ and $\mathrm{Pt} / \mathrm{Pd}$ nanoparticles supported on poly 1,8-diaminonaphthalene film in alkaline medium, RSC Adv., 2018, 8, 1541715426.

52-P. Zuman, Substituent Effects in Organic Polarography, Plenum Press, New York, NY, 1967.

53-F. G. Thomas, K. G. Boto, The Chemistry of the Hydrazo, Azo and Azoxy Groups, John Wiley, London, 1975.

54-D. K. Gosser, Cyclic voltammetry : simulation and analysis of reaction mechanisms, $\mathrm{VCH}$, New York, 1993.

55-M. S. Mahmoud, J. Y. Farah, T. E. Farrag, Enhanced removal of Methylene Blue by electrocoagulation using iron electrodes, Egypt. J. Pet., 2013, 22, 211-216. 